\title{
Effects of starvation on moult cycle and hepatopancreas of Stage I lobster (Homarus americanus) larvae
}

\author{
K. Anger ${ }^{1}$, V. Storch ${ }^{2}$, V. Anger ${ }^{1} \&$ J. M. Capuzzo ${ }^{3}$ \\ ${ }^{1}$ Biologische Anstalt Helgoland (Meeresstation); D-2192 Helgoland, \\ Federal Republic of Germany \\ ${ }^{2}$ Zoologisches Institut der Universitât Heidelberg; Im Neuenheimer Feld 230; \\ D-6900 Heidelberg, Federal Republic of Germany \\ ${ }^{3}$ Woods Hole Oceanographic Institution, CRC; Woods Hole, Massachusetts 02543, USA
}

\begin{abstract}
Effects of feeding and starvation on the moult cycle and on the ultrastructure of hepatopancreas cells were studied in Stage I lobster larvae (Homarus americanus Milne-Edwards). The relative significance of yolk and first food was quite different in larvae originating from two females. This difference was evident also in the amounts of stored lipid in the R-cells of the larval hepatopancreas. Most larvae from one hatch were, in principle, able to develop exclusively with yolk reserves (without food) to the second instar. The larvae from the second hatch showed lecithotrophic development only to the transition between late intermoult and early premoult (Stages $\mathrm{C} / \mathrm{D}_{0}$ of Drachs's moult cycle) of the first larval instar. When initial starvation in this group lasted for 3 days or more, the point of no return (PNR) was exceeded. After the PNR, consumption of food was still possible, but development ceased in the transition $C / D_{0}$ or in late premoult $\left(D_{3-4}\right)$. It is suggested that these stages of the moult cycle are critical points were cessation of development and increased mortality are particularly likely in early larval lobsters under nutritional stress. Examination of hepatopancreas R-cells suggested that the PNR is caused by an irreversible loss of the ability to restore lipid reserves depleted during initial starvation. Initial periods of starvation ending before the PNR prolonged mainly Stage $D_{0}$ of the same instar (I). During this delay, structural changes in the R-cells caused by the preceding period of starvation were reversed: reduced lipid inclusions, swollen mitochondria, an increased number of residual bodies indicating autolysis, and a reduction of the microvillous processes. Continually starved larvae which showed lecithotrophic development throughout the first instar and were then re-fed after moulting successfully, had later a prolonged intermoult (Stage C) period in the second instar. This shows that, despite occasional lecithotrophy, food is an important factor in early larval development of the lobster.
\end{abstract}

\section{INTRODUCTION}

The American lobster, Homarus americanus, is subject to locally important commercial fisheries, and increasingly, to efforts in aquaculture (for recent reviews see Dow, 1980; van Olst et al., 1980). Nutritional requirements of juvenile and adult lobsters are fairly well known (Conklin, 1980; Capuzzo, 1982), whereas those of larvae are less understood. Substantial progress in the knowledge of biochemistry and physiology of lobster ontogeny has recently been made in the extensive work by Sasaki (1984). It showed that first feeding of freshly hatched larvae may play a significant role for further development, as a number of essential fatty acids and other components of food are usually not contained in sufficient amounts in the egg yolk, and they cannot be 
synthesized de novo from simple precursors. However, there is also indication of partial lecithotrophic development in early lobster larvae (Carlberg \& van Olst, 1976). Since Sasaki (1984) found a $D_{0}$ threshold in lobster larvae similar to that observed by Anger (1984) in larval brachyurans (Hyas araneus), similar interactions between feeding conditions and the moult cycle might be presumed in different crustacea. It was one of the aims of this study to give a preliminary account of such interactions in early larval development of Homarus americanus and to compare them with those found in Hyas araneus, in order to assess the relative significance of yolk and food.

Another point is the study of effects of feeding and starvation on the ultrastructure of the larval hepatopancreas. Such effects may be used as an indicator of nutritional conditions in crustacea (Storch, 1984; Storch \& Burkhardt, 1984; Vogt et al., 1985). The only comparable study on decapod larvae so far available is that by Storch \& Anger (1983) on Hyas araneus.

\section{MATERIAL AND METHODS}

\section{Obtaining and handling of larvae}

Ovigerous Homarus americanus Milne Edwards were obtained from the Massachusetts State Lobster Hatchery on Martha's Vineyard, and transported to a laboratory of the Woods Hole Oceanographic Institution, Woods Hole. They were maintained in glass aquaria supplied with well-aerated, flowing sea water (30-31\%S) at ambient temperatures $\left(21-23^{\circ} \mathrm{C}\right)$. Larvae which hatched on 5 July and $8 \mathrm{July}, 1984$, from 2 different females, were used for this study.

Freshly hatched Stage I larvae were transferred to compartmented polypropylene trays with the bottom replaced by nylon gauze (1-mm mesh size), and maintained individually. The trays floated in water tables supplied constantly with aerated filtered $(10 \mu \mathrm{m})$ sea water $\left(30-31 \% \mathrm{~S}_{\text {; }}\right.$ flow rate ca $\left.1.51 \cdot \mathrm{min}^{-1}\right)$. Temperature during the experiments ranged from 21 to $25^{\circ} \mathrm{C}$ (mean \pm standard deviation: $23.0 \pm 1.1^{\circ} \mathrm{C}$ ).

The larvae were checked every $12 \mathrm{~h}$ and (if applicable; see below) fed frozen adult Artemia ( 3 per larva), after uneaten brine shrimps from the last feeding had been removed.

\section{Experiments}

The following experimental design was chosen to determine the point of no return (PNR; Anger \& Dawirs, 1981), and effects of starvation and re-feeding: 64 larvae were treated as described above throughout the experiment (fed control group), whereas all the others were starved from hatching; every $24 \mathrm{~h}$ another group of 64 larvae was fed for the first time, and from then on treated in the same way as the control group. 32 larvae within each group were reared exclusively for determination of development and survival rate to the second larval instar, 16 were used for moult staging, and again 16 for sampling hepatopancreas.

\section{Moult staging}

Every $12 \mathrm{~h}$, from each experimental group, 6 larvae were chosen at random and pipetted to a glass bowl. Then they were placed on a slide, and their telson was examined under a microscope. The stage of the moult cycle was determined according to 
the criteria given by Sasaki (1984), and the larvae were transferred back to a bowl, and from there to their tray compartments. The larvae developed without signs of damage exerted by this moult-staging technique. Also larvae which died in the experiments were moult staged, if possible.

\section{Electron microscopy}

Samples of hepatopancreas were taken in the following way: larvae were dissected in a cold solution of $3 \%$ glutaraldehyde and $7.5 \%$ sucrose in $0.1 \mathrm{M}$ Sörensen's buffer (pH 7.4) under a stereo microscope. The isolated tissues were transferred to another vial with the same solution and stored for ca $1.5 \mathrm{~h}$ in a refrigerator. After washing the material 5 times for $5 \mathrm{~min}$ in cold Sörensen phosphate buffer (with $7.5 \%$ sucrose), it was postfixed for another $2 \mathrm{~h}$ in buffered $\mathrm{OsO}_{4}(1 \%)$, rinsed repeatedly in Sörensen phosphate buffer, dehydrated through a graded series of ethanols, and embedded in araldite. The samples were sectioned (with glass and diamond knives) and stained with uranyl acetate (saturated solution in $70 \%$ methanol) and lead citrate. Sections were examined in a Zeiss EM 9 S-2 electron microscope.

\section{RESULTS}

\section{Moult cycle}

The approximate course of the stages of the moult cycle is shown in Figures 1 and 2 (upper graphs) for the control larvae of the two hatches examined. The postmoult stages $\mathrm{A}$ and $\mathrm{B}$ were completed in both hatches within less than $12 \mathrm{~h}$ after hatching, regardless of conditions of feeding or starvation.

The average duration of intermoult (Stage C) of continuously fed larvae was ca $12 \mathrm{~h}$ in the first, and almost $20 \mathrm{~h}$ in the second hatch. Early premoult $\left(\mathrm{D}_{0}\right)$ lasted in both
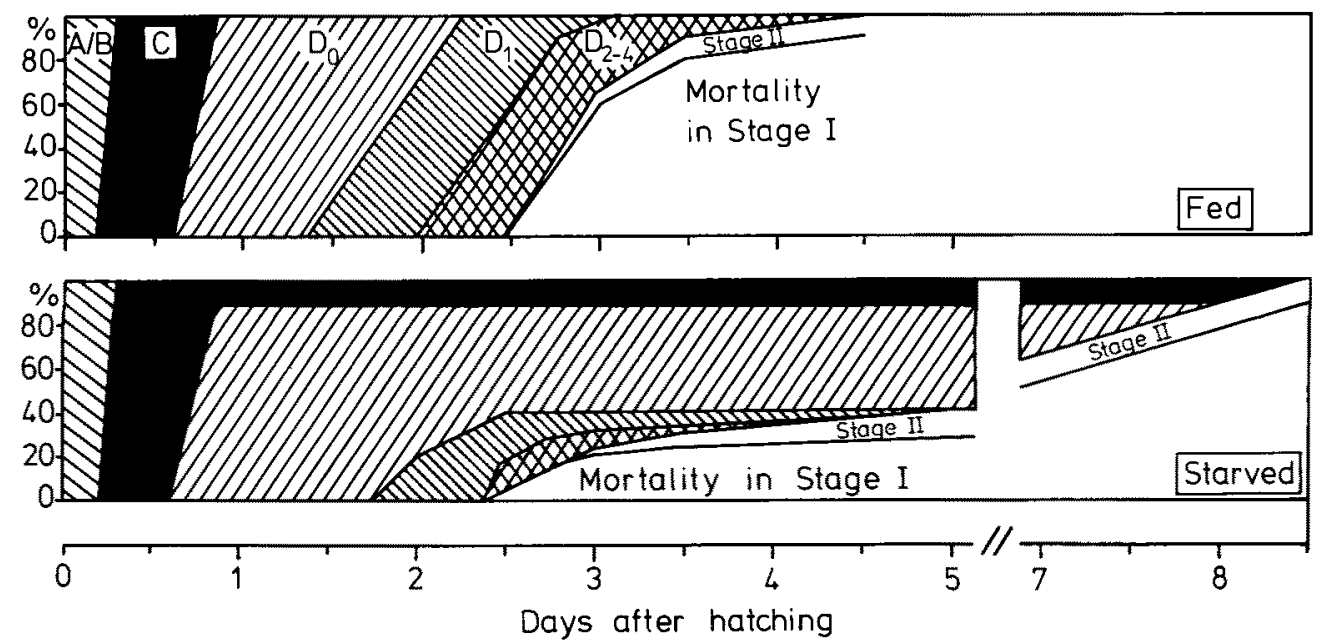

Fig. 1. Homarus americanus: Relative frequency (\%) of events of the moult cycle and mortality during development in fed and starved Stage I larvae; first hatch 

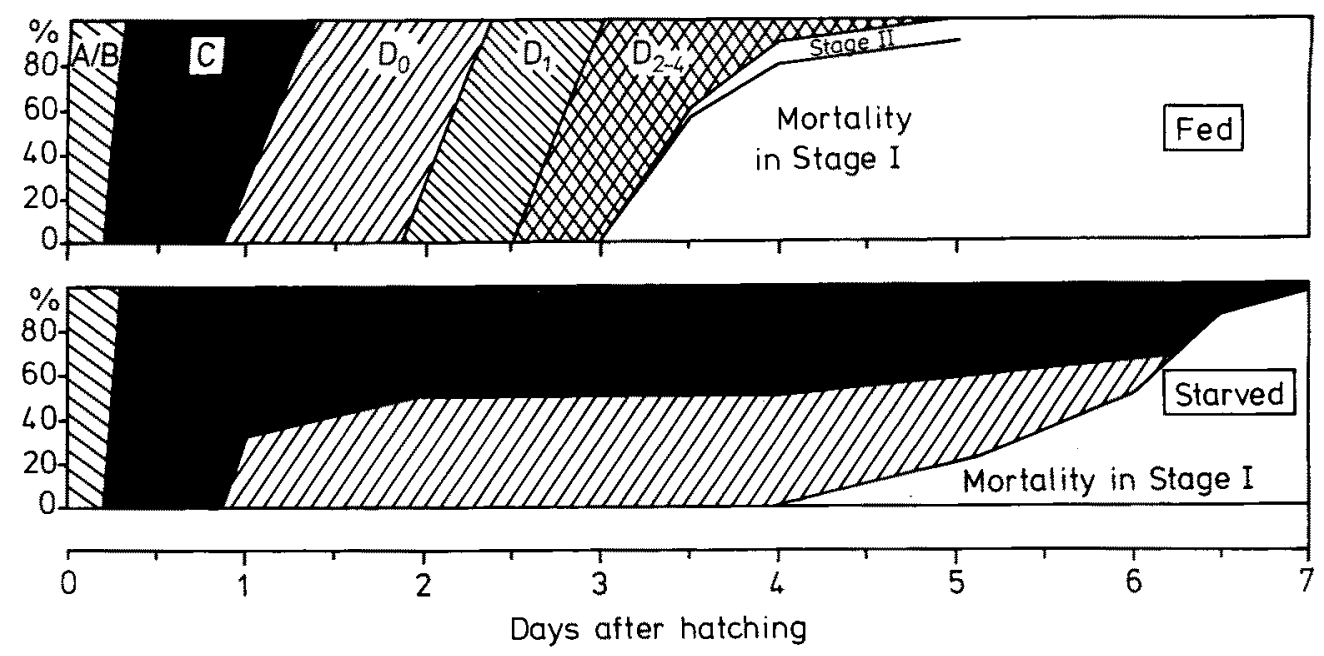

Fig. 2. Homarus americanus; for explanation see Fig. 1; second hatch

groups, on the average, ca $24 \mathrm{~h}$, with somewhat higher individual variation in the former than in the latter group. Intermediate premoult $\left(D_{1}\right)$ was also similar in larvae from both hatches (ca $15 \mathrm{~h}$ ), whereas late premoult $\left(\mathrm{D}_{2-4}\right)$ was slightly delayed in the second group (ca 16 vs $12 \mathrm{~h}$ ).

The complete moult cycle from hatching to reaching the second larval instar thus lasted, on the average, somewhat less than 3 days in the first, and 3.5 days in the second hatch. The delay in the second group was caused by prolonged intermoult (C) and, to a lesser degree, late premoult $\left(D_{2-4}\right)$.

In both experiments there was extremely high mortality during the moulting process (Figs 1 and 2: "mortality in Stage I"), regardless of the experimental (feeding/starvation) conditions. This observation will be discussed below.

Figures 1 and 2 (lower graphs) show that major differences were found in the responses of larvae from the two different hatches to continual starvation. Surprisingly, most larvae from the first hatch reached at least Stage $D_{0}$, many also $D_{1}$, and ca $11 \%$ (about the same percentage as in the fed control!) moulted successfully to the second instar, although they were not fed (Fig. 1). Apparently, the larvae of the second hatch had lower yolk reserves which did not allow lecithotrophic development through the first instar (Fig. 2). Their development ceased in most cases at the transition between Stages $C$ and $D_{0}$, i.e. they showed the expected failure at the $D_{0}$ threshold.

Figures 1 and 2 (lower graphs) show another important tendency: larvae whose development ceased in an earlier stage of the moult cycle survived longer than further advanced larvae. In the first hatch this can be seen in moult-related mortality after 2.5 to 3 days after hatching (parallel to the fed control). Most larvae which died later were found to be in Stage $D_{0}$. The very last larvae which survived up to 8 days of starvation were still in Stage $C$ or in very early $D_{0}$. Also in the second hatch (Fig. 2), larvae which reached late parts of Stage $D_{0}$ died first, followed later by those which stayed in early $D_{0}$ or late C. Epidermal apolysis occurred in many Stage C individuals as a premortal effect. The retraction process, however, looked different from that in healthy $D_{0}$ larvae. It was probably caused by the shrinking and progressive disintegration of the epidermis. 
Effects of temporary initial starvation on development were partly veiled in the first hatch, since many larvae had enough yolk reserves to advance through all or some premoult stages. Moult staging, however, showed quite clearly that the postmoult and intermoult stages $(\mathrm{A}-\mathrm{C})$ were not significantly affected by any period of initial starvation. Most larvae reached almost simultaneously Stage $D_{0}$. Many of them developed through further stages, regardless of feeding or starvation (Fig. 1), whereas in other larvae effects of food deprivation could be observed: premoult Stages $D_{0}$ and (less) $D_{1}$ were prolonged. This effect was weak after 1 day, but obvious after 2 days of initial starvation. Afer a 3-day lack of food, those larvae which had not been able to develop beyond Stage $D_{0}$ with own yolk reserves, apparently reached the PNR and could not recover after being re-fed.

This did not apply to those larvae which had lecithotrophic development and moulted to the second instar, 3 days after hatching. They accepted and converted food which was offered right after moulting, and they successfully developed through the second instar. However, the lack of food during the entire first instar caused a significant delay (by 1-2 days) in their intermoult (Stage C) duration of the second instar (which was continously fed). Also 2 days of initial starvation (during instar I) caused a slight delay in Stage C development of instar II, whereas only 1 day of starvation had no clear effect. This shows that even larvae which are, in principle, able to develop exclusively with yolk reserves to the second instar, suffered from food deprivation. In this case, the effects of starvation became visible only in instar II, where intermoult was prolonged until accumulation of energy and matter from food allowed further development beyond the $\mathrm{D}_{0}$ threshold.

In the second hatch, ca one half of the larvae reached Stage $D_{0}$, independent of food. Again, initial starvation mainly delayed the completion of early premoult $\left(D_{0}\right)$, and this effect was much stronger after 2 days than after 1 day of starvation. After 3 days of food deprivation and re-feeding-Stages $D_{0}$ and $D_{1}$ were strongly prolonged (in total by more than 3 days). These larvae died later, mostly in late premoult without moulting to the second instar (i.e. they all had already surpassed the PNR). All larvae which were initially starved for 4,5 , or 6 days remained at the transition between late $C$ and early $D_{0}$ i.e. they behaved in the same way as continuously starved individuals (Fig. 2). It could be clearly observed that also these larvae easily accepted food and filled their stomachs but did not develop further. Thus, the PNR was not caused by inability to eat but by an other irreversible damage which stopped development in early premoult.

\section{Hepatopancreas}

The epithelium of the hepatopancreas of larval Homarus americanus is composed of the clearly distinguishable cell-types described from other decapods (R-, F-, B-cells, which all arise from E-cells). It was mainly the ultrastructure of the R-cells which changed considerably after starvation.

In the investigated Stage I larvae of Homarus americanus, the R-cells, which were predominant in number, stored large amounts of lipid droplets of different diameter. These inclusions are considered the striking feature in freshly hatched and well-fed larvae. They can be much larger than the cell nuclei and do not exhibit any substructure (Fig. 3a). After food deprivation the stored lipid was reduced markedly; this was even 

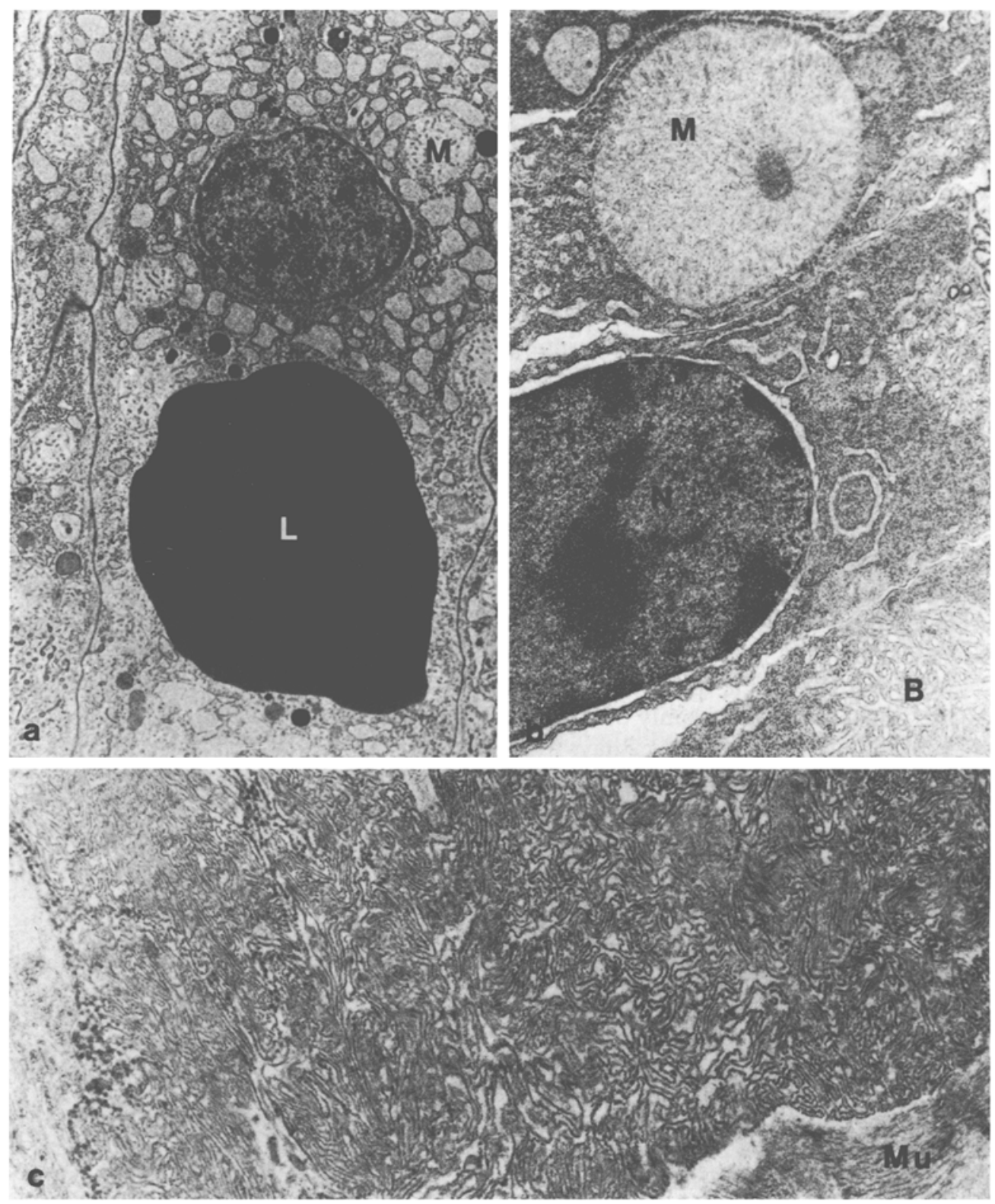

Fig. 3. Homarus americanus: hepatopancreas of Stage I larvae. (a) R-cell of a freshly hatched larva (5200:1); (b) R-cell: starvation period 6 days (9200:1); (c) basal lamina: starvation period 6 days $(9200$ : 1). L: lipid inclusion; M: mitochondrium; Mu: muscle cell; $\mathrm{N}$ : nucleus 
obvious after only one day. From the third day after cessation of feeding, only single cells contained very small lipid inclusions. Refeeding after a short period of starvation (1-2 days) resulted always in a reestablishment of the lipid contents; from day 3 the response varied; 5 days of food deprivation apparently made absorption of lipid in R-cells impossible.

The R-cells of our experimental animals never contained glycogen. In freshly hatched and fed animals the cell nucleus was surrounded by ribosome-studded endoplasmic reticulum, small Golgi fields, and mitochondria. In the course of starvation the mitochondria became swollen (Fig. 3b). They reached nearly the size of the cell nucleus. The endoplasmic reticulum of later stages of starvation was found broken up into vesicles or exhibited dilated profiles, Golgi fields were lacking. Residual bodies indicating autolysis increased in number from the first day of food deprivation.

The microvillous border was highly developed in freshly hatched and fed larvae. In starved animals a reduction of the microvillous processes was observed. Extreme alterations of the basal lamina were found in some animals in an advanced stage of starvation (Fig, 3c).

The main difference between hatch I and hatch II larvae was in the amount of lipid material stored in the R-cells. Refeeding after a starvation period of 3 days resulted in a total regeneration in hatch I larvae, whereas this was not the case in hatch II larvae. After 1 day of refeeding, the R-cells of the last mentioned group corresponded to 3-day starved R-cells of hatch I larvae. Food deprivation of 3 days left the animals originating from hatch II with small and flattened R-cells without lipid inclusions. This did not change even after refeeding for 1.5 days.

\section{DISCUSSION}

The relative significance of yolk and first feeding in early larval development of the American lobster shows a high degree of variability. The larvae from two hatches differed markedly in their amounts of lipid reserves stored in the R-cells of the hepatopancreas. These cells are considered good indicators of nutritional conditions, since they absorb nutrients from the glandular lumen and store organic reserves (for literature see Storch \& Anger, 1983; Storch, 1984). In one hatch, many Stage I larvae revealed lecithotrophic development, though effects of initial lack of food became visible later, in the second instar. The larvae of another hatch remained in Stage $C$ or $D_{0}$ of their first moult cycle when they were starved from hatching. Also Sasaki (1984) found such a $\mathrm{D}_{0}$ threshold similar to that in Brachyuran larvae (Anger, 1984). Carlberg \& van Olst (1976), in contrast, reported lecithotrophic development of Homarus americanus even to the third larval instar. However, this might have been an artifact caused by a "constant temperature phenomenon" as noted by Sasaki (1984).

Strong variability, even among sibling lobsters, has been described also in growth rates (e.g. Hedgecock et al., 1976; van Olst \& Carlberg, 1978). Besides genetic factors, also size, age, and nutrition of the female during oogenesis, as well as temperature etc. during both oogenesis and embryogenesis might play significant roles for the quantity and quality of reserves in the freshly hatched larva (e.g. Sasaki \& Capuzzo, in press). Also larvae hatching on subsequent nights from the same female may be different (Pandian, 1970). Thus, it cannot be determined, what caused the significantly different 
amounts of lipid reserves and the consequently different responses to periods of initial starvation in larvae from two different hatches. The only difference which could easily be seen was, in this case, the size of the ovigerous female: the first hatch (showing stronger resistance against starvation stress) originated from a much larger female than the second hatch.

In all our experiments there was slow development (cf. Carlberg \& van Olst, 1976; Sastry \& Zeitlin-Hale, 1977; Logan \& Epifanio, 1978) and very high mortality in moult from the first to the second larval instar. Besides low viability of both hatches, a possible cause might have been the lack of water movement which is known to be important for Homarus larvae (e.g. Auteri, 1975; van Olst et al., 1980). It could not be provided, because a high number of larvae had to be maintained individually. On the other hand, similar rearing techniques had been used successfully by Carlberg \& van Olst (1976) and Logan \& Epifanio (1978). Also the food might have been insufficient, perhaps in combination with the lack of turbulence: van Olst et al. (1980) reported that live brine shrimps yield better results than frozen ones, and Bowser \& Rosemark (1981) found in young lobsters a "moult-related mortality syndrom associated with diet". The crucial component of the diet is probably fatty acids (Sasaki, 1984). Specific improvements of rearing techniques for this type of study thus may in future be necessary.

Despite this problem, a number of interesting observations could be made as to interactions between moult cycle events, yolk and nutrition. Critical points could be detected in the transition between Stages $C$ and $D_{0}$, and in $D_{3-4}$. Another critical point which is already well known in arthropod development is the moulting process itself (Stage E). Yolk reserves (or a brief early feeding period) may suffice to support successful development through all of these phases, in some cases even through at least two complete moult cycles (Carlberg \& van Olst, 1976). In other cases, however, development will cease in one of the critical points, i.e. a larva is much more likely to die in one of these stages of the moult cycle (transition $C / D_{0}, D_{3-4}, E$ ) than in others. It appears that the slightest degree of lecithotrophy leads to late Stage C (present results; Sasaki, 1984; Anger, 1984).

There is also evidence that the time which may be spent in one of these critical points decreases with increasing development within the moult cycle: larvae which have initiated the moulting process will either moult or die very soon, whereas those stuck in late premoult may survive in this stage for up to a few days. Larvae whose development ceased, due to initial starvation and low yolk reserves, in late intermoult or early premoult $\left(C / D_{0}\right)$ are able to survive the longest time under continued starvation. If this period of food deprivation lasts too long, these larvae may reach the point of no return (PNR), i.e. when re-fed they will stay in their present stage of development (usually C/ $\left.D_{0}\right)$ or they may develop to the next critical point $\left(D_{3-4}\right)$, but will not complete the moult cycle (present observations; cf. Anger, 1984).

Electron-microscopial evidence suggests that there is an irreversible loss of the capability to absorb and store lipid in the R-cells of the hepatopancreas, after the PNR has been surpassed. This effect had been found also in crab larvae (Storch \& Anger, 1983), and it may be the general "irreversible damage" postulated by Anger \& Dawirs (1981).

In contrast to starved and refed Hyas araneus (Storch \& Anger, 1983), our lobster larvae never had glycogen inclusions in their R-cells. Also Vogt et al. (1985) found that 
glycogen was lacking in the midgut glands of Penaeus monodon, whereas several authors (for discussion see Storch \& Anger, 1983), did find it in other crustaceans.

Initial starvation periods ending before the PNR prolong mainly Stage $D_{0}$ of early non-lecithotrophic lobster larvae. In Brachyuran larvae (Hyas araneus) this "buffer zone" of development in which accumulation of energy and matter is made up for, appears to be earlier, in Stage C (Anger, 1984). The main period of physiological stability in which organic reserves are accumulated is, according to Aiken (1980 and earlier papers cited therein), somewhat later in lobsters than in other decapods, i.e. at a transition between late $C$ and $D_{0}$.

Acknowledgements. This study is a contribution to research project An-145/1-1 granted by the Deutsche Forschungsgemeinschaft. The first author is indebted to the Biologische Anstalt Helgoland and Woods Hole Oceanographic Institution for financial support, and to Mrs. P. Biesiot, Dr. B. A. Lancaster, and Mr. D. Leavitt for help. Miss B. Lämmel made the line drawings. Miss R. Mummert took the sections for electron microscopy.

\section{LITERATURE CITED}

Aiken, D. E., 1980. Molting and growth. In: The biology and management of lobsters. Ed. by J. S. Cobb \& B. F. Phillips. Acad. Press, New York, 1, 91 163.

Anger, K., 1984. Influence of starvation on moult cycle and morphogenesis of Hyas araneus larvae (Decapoda, Majidae). - Helgoländer Meeresunters. 38, 21-33.

Anger, K. \& Dawirs, R. R., 1981. Influence of starvation on the larval development of Hyas araneus (Decapoda, Majidae). - Helgoländer Meeresunters. 34, 287-311.

Auteri, R., 1975. Ricerche sperimentali sullo sviluppo di Homarus gammarus (Crostaceo, Decapode). - Pubbl. Staz. zool. Napoli 39 (Suppl.), 1-6.

Bowser, P. R. \& Rosemark, R., 1981. Mortalities of cultured lobster, Homarus, associated with a molt death syndrome. - Aquaculture 23, 11-18.

Capuzzo, J. M., 1982. Crustacean bioenergetics: the role of environmental variables and dietary levels of macronutrients on energetic efficiencies. - Spec. Publ. Wld Maricult. Soc. 2, 71-86.

Carlberg, J. M. \& Olst, J. C. van, 1976. Brine shrimp (Artemia salina) consumption by the larval stages of the American lobster (Homarus americanus) in relation to food density and water temperature. - Proc. a. Meet. Wld Maricult. Soc. 6, 379-389.

Conklin, D. E., 1980. Nutrition. In: The biology and management of lobsters. Ed. by J. S. Cobb \& B. F. Phillips. Acad. Press, New York, 1, 277-300.

Dow, R. L., 1980. The clawed lobsters fisheries. In: The biology and management of lobsters. Ed. by J. S. Cobb \& B. F. Phillips. Acad. Press, New York, 2, 265-313.

Hedgecock, D., Nelson, K. \& Shleser, R., 1976. Growth differences among families of the lobster, Homarus americanus. - Proc. a. Meet, Wld Maricult. Soc. 7, 347-361.

Logan, D. T. \& Epifanio, C. E., 1978. A laboratory energy balance for the larvae and juveniles of the American lobster Homarus americanus. - Mar, Biol. 47, 381-389.

Pandian, T. J., 1970. Yolk utilization and hatching time in the Canadian lobster Homarus americanus. - Mar. Biol. 7, 249-354.

Sasaki, G. C., 1984. Biochemical changes associated with embryonic and larval development in the American lobster Homarus americanus Milne Edwards. Ph. D. Thesis, Woods Hole Oceanographic Institution, Woods Hole, Mass., Massachusetts Institute of Technology, Cambridge, Mass., $458 \mathrm{pp}$.

Sasaki, G. C. \& Capuzzo, J. M., 1985. Biochemical aspects of crustacean development and metamorphosis: 1. Embryogenesis and hatching of the American lobster Homarus americanus Milne-Edwards. - Biol. Bull, mar. biol. Lab., Woods Hole (in press).

Sastry, A. N. \& Zeitlin-Hale, L., 1977. Survival of communally reared larval and juvenile lobsters, Homarus americanus, - Mar. Biol. 39, 297-303.

Storch, V., 1984. The influence of nutritional stress on the ultrastructure of the hepatopancreas of terrestrial isopods. - Symp. zool. Soc. Lond. 53, 167-184. 
Storch, V. \& Anger, K., 1983. Influence of starvation and feeding on the hepatopancreas of larval Hyas araneus (Decapoda, Majidae). - Helgoländer Meeresunters. 36, 67-75.

Storch, V. \& Burkhardt, P., 1984. Influence of nutritional stress on the hepatopancreas of Talitrus saltator (Peracarida, Amphipoda). - Helgoländer Meeresunters. 38, 65-73.

Van Olst, J. C. \& Carlberg, J. M., 1978. The effects of container size and transparency on growth and survival of lobsters cultured individually. - Proc. a Meet. Wld Maricult. Soc. 10, 469-479.

Van Olst, J, C., Carlberg, J. M. \& Hughes, J. T, 1980. Aquaculture. In: The biology and management of lobsters. Ed. by J. S. Cobb \& B. F. Phillips. Adac. Press, New York, 2, 333-384.

Vogt, G., Storch, V., Quinitio, E. T. \& Pascual, F. P., 1985. Hepatopancreas as monitor organ for the nutritional value of diets in Penaeus monodon (Decapoda), - Aquaculture (in press). 